\title{
A Study on the English Teaching of Minority Preparatory Education and the Role Change of English teachers Based on the Flipped Classroom
}

\author{
Xijuan Chen \\ Nanchang Institute of Science and Technology \\ Nanchang, Jiangxi, China 330108
}

\begin{abstract}
Under the background of big data era, an education storm of "flipped classroom" has triggered a close attention in educational circles, as well as the discussion of it. This paper focuses on the "flipped classroom", which is applied to English teaching of minority preparatory education, and can be used to explore its impact on the minority preparatory education and the role change of English teachers.
\end{abstract}

Keywords-flipped classroom; minority preparatory education; English teaching; role change of English teachers

\section{INTRODUCTION}

Piaget and Bruner's view on cognition has gradually been formed the well-known model of Constructivism Theory. And the flipped class is a brand new teaching model derived from the theory.

In 1990s, the flipped learning was integrated by Professor from Harvard University with the "companion" teaching method founded by Eric Mazur. Before the class, the students are required to watch the video, read the articles, think about the answers to the problems, and then review the knowledge they have learned, put forward questions, and solve the problems. In 2007, a teacher of a high school in North America firstly took the flipped classroom into practice. The new teaching mode which is organized with self-study video in extracurricular time, mainly completing homework and experiments, solving students' learning difficulties in the class, has subverted the traditional mode of teaching in the class, forming a reversal teaching mode. Since Sahlman Khan introduced the flipped classroom to the world at the TED conference in 2011, it has attracted much attention and become one of the hot spots in world educational circles in the recent years. ${ }^{[1]}$

This mode is especially suitable for the class in which students are in different English levels. Students in minority preparatory classes are from different ethnic minorities all over the country. Thus, English levels vary considerably. The traditional teaching is difficult to teach and estimate each student in the class, while the flipped classroom can be targeted to help students' autonomous learning, as well as the individual counseling.

\section{The Teaching Mode of FlipPed Classroom}

The traditional mode of teaching is based on teaching the new knowledge in the classroom, and students completing the internalization of knowledge after the class, namely to review and do homework. But instead of the traditional teaching, the flipped class is in the other way. The teachers will take the recording video uploaded in the Internet and share with students. Students are required to watch the video before the class, and in the class, the teacher is no longer give lectures, but to provide the necessary guidance for the students and help the students in need. Therefore, students become the leading role in the learning process. And they can independently arrange extracurricular learning time, and take the initiative to explore the problem; in the class, they can ask the teacher or discuss with their classmates to solve problems encountered in the assignment or in the process of extracurricular learning ${ }^{[2]}$.

Thus, the flipped learning is involved with video learning firstly, and inquiry, cooperation, discussion under the guidance of the teacher. Supported by information technology and digital resources, it is a new teaching mode flipped with the learning activities and tasks before and after classes.

\section{THE APPLICATION OF FLIPPED CLASSROOM IN THE ENGLISH TEACHING OF MINORITY PREPARATORY EDUCATION}

According to the teaching experience, Professor Robert Talbert in Franklin Institute of America has summarized a structure chart of the flipped classroom. Based on his chart and the characteristics of the English teaching of minority preparatory education, the following chart of teaching process is designed.

\section{A. Before the Class}

1) Teachers collect and make relevant teaching courseware and teaching video: In the teaching mode of flipped classroom, students' autonomous learning occupies a large proportion, such as watching the video by themselves before the class. So, before making the teaching video, teachers should firstly get to know the students' knowledge level, learning ability and learning interest, and pay 
attention to the combination of listening, speaking materials, the students' interest and knowledge level. Secondly, the video should not be too long, so 20 minutes is appropriate. In addition, in every link of teaching, teachers should prepare specific teaching objectives and design related exercises for testing.

2) Students learn the video by themselves, and participate in online communication: In the English Teaching of Minority Preparatory Education, it takes a long time for students to stay in the classroom, from the early learning in the morning to evening self-study, so the time for students to watch the video can be unified in a certain period of time, like the time in early learning and evening self-study. The video is available for download, so the students can also choose a spare time to watch. When learning from the video, students can write down questions they want to ask and then discuss with classmates or teachers in the classroom. It is better for teacher to raise certain questions for students to think over when learning from the video. In the traditional class, students usually tend to be shy, and they do not dare to speak in English. But, they can practice English in a free way when watching the video, without any intervention.

Among the students and teachers, they are able to discuss and communicate through the online exchange platform, such as QQ group, WeChat circle. In the traditional classroom, many students feel quite nervous when they communicate with their teachers, while in the communication platform, students can choose to be anonymous to communicate, so they are more willing to discuss. The students can even communicate in English with others through the online platform, which can help students improve their English application ability. The preparation before the class is shown as following " Fig. 1".

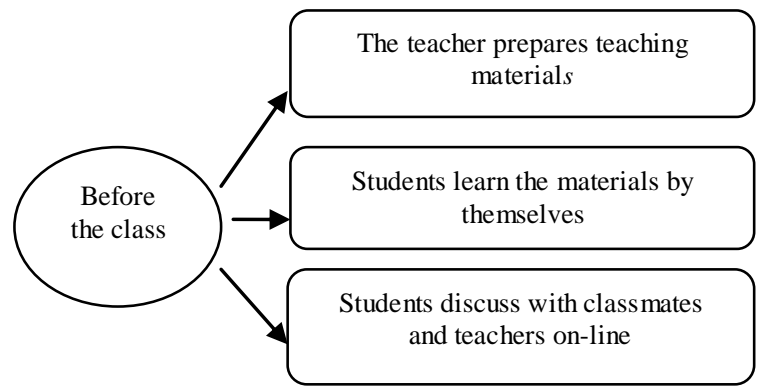

Fig. 1. The preparation before the class.

\section{B. During the Class}

1) The teachers sum up and arrange the layout of the task: Through online discussion, teachers are required to summarize the main problems, explain the problems and then arrange the layout of the tasks in the class, such as requiring students to recite words and doing dictation in groups, English translation, English dialogue practice in groups, discussing on a particular topic in English, and listing all the views and so on.
2) Students study in group cooperation, and the teacher is in charge of the guidance: In the flipped classroom, the students are required to complete the tasks assigned by the teacher through group discussion. Students in their groups help each other with mutual supervision and mutual learning. The students whose performance is limited generally do not dare to ask the teacher for the answers, and they are more willing to ask the classmates. The students with good performance will be improved and strengthened in helping classmates with solving their learning problems. Not only the knowledge will be strengthened but also a sense of achievement can be attained. In the moment, the teachers are required to listen, observe, help, encourage and guide, who should play a supporting role.

3) Task completion, summary and test: Students are required to make a summary in each study group firstly, sharing in the classroom. The forms of the summary are encouraged to be in diversity, such as the form of an English dialogue, a presentation and so on. According to their results, teachers are required to listen, observe, and then do the final summary or participate in testing. "Fig. 2" is shown in the belows.

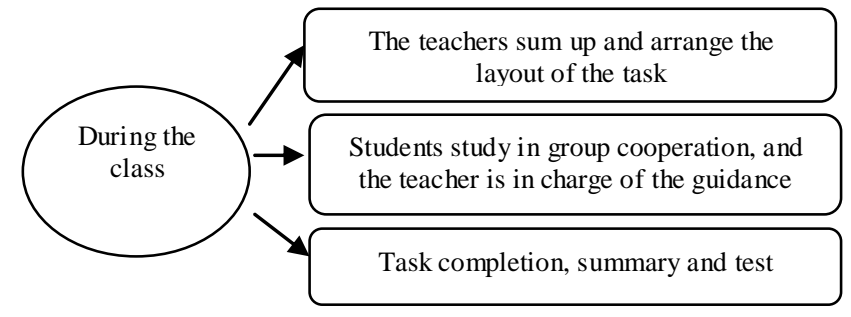

Fig. 2. The classroom design.

\section{After the Class}

After the class, if the students have certain doubts on the new knowledge, they can watch the video again or communicate with teachers through online discussion and strengthen the knowledge through the review of the video. Teachers summarize and make the reflection after the class, which is can be a rich experience for the next time. After the class, teachers should find some problems in students' assignment and discussion according the completion of the learning goals in the class. And the teachers should also timely make a summary of the entire teaching process and teaching contents. What's more important, they should reflect the problems in the teaching process, and avoid the same problem in the future teaching. In addition, teachers should also take certain time to communicate with the students, to understand the learning needs of students, and encourage students to put forward advice and suggestions of learning and teaching.

The entire teaching process is shown in "Fig. 3" 


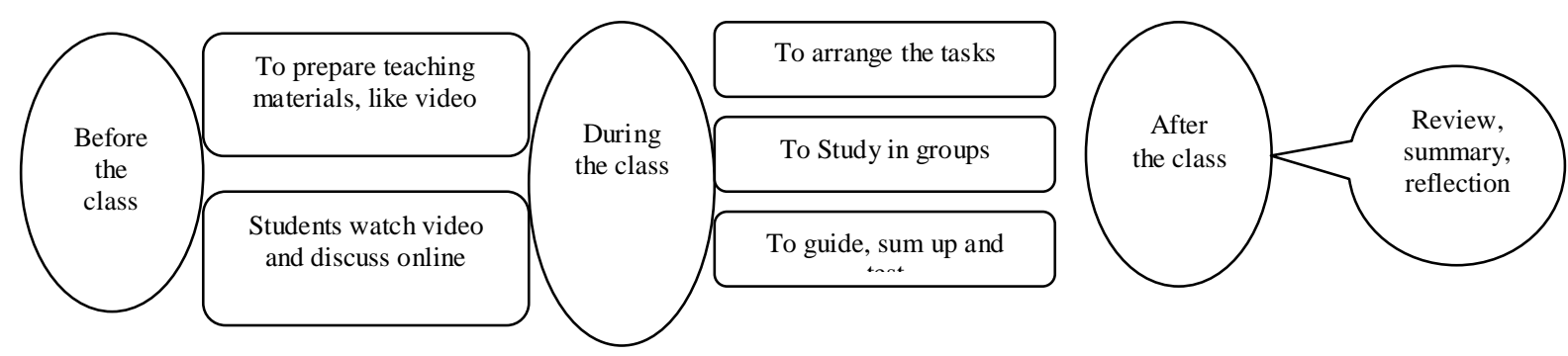

Fig. 3. The entire teaching process.

\section{THE AdVANTAgES OF THE FLIPPED ClASSROOM}

In the flipped classroom, students can study independently. Autonomous learning refers that students can positively and consciously engage in and manage their own learning activities, rather than passive learning under the various pressures and demands. ${ }^{[3]}$

Students autonomously arrange time to learn the video. When they do not understand the content in the video, they can playback, if it needed, they can even watch the whole video again. This is one of the advantages that the traditional teaching methods can be incomparable. The traditional classroom, many students are busy with taking notes, and do not have enough time to completely understand all the teaching contents.

When students encounter difficulties in the learning process, they have to try to solve the problems by themselves because the teacher is not around, which can cultivate the students' independence and ability to independently solve problems. With the accumulation of students' self learning experience, the learning consciousness of the students will become stronger, and the control, judgment and evaluation ability for the self-learning activities, will be continually enhanced. Thus, their ability of independent learning can develop to the advanced level. ${ }^{[2]}$

Teaching can be considered as a bilateral activity between teachers and students, and the teacher-student relationship is the basic relationship to maintain teaching activities. ${ }^{4]}$ In the flipped classroom, the teacher is no longer the "sage on the platform", but going down the platform, becomes the students' mentor and friend. The teacher is no longer the master of the discourse right in the class, and students do not only obediently listen to the teacher and take notes. They can freely communicate with the teachers on the problems encountered in the process of learning. The distance between teachers and students both in space and in psychology are greatly shortened. It is obvious for students to promote their study. The encouragement will enhance students' learning motivation, and the patient guidance will help students establish confidence. A close partnership between teachers and students will gradually form to promote the development of classroom teaching to the benign direction.
In the flipped classroom, all learning activities are organized in a student-centered pattern. The teachers only give the necessary guidance in the learning process, and are no longer superior "authority of education". ${ }^{[5]}$

Teachers should also give students enough respect and support the students' any meaningful learning behavior. When students gain the teacher's respect and support, they will make in response, such as to return the teachers' respect by working hard. In this process, the students' learning initiative will vastly be improved.

\section{The Transformation OF the TEACHER' Role}

According to the above teaching process and advantages of the flipped classroom, the role of teachers has also been transformed. ${ }^{[6]}$ In the big data era, English teachers should adjust the position and role in teaching, which can adapt to the development in a better way.

\section{A. The role of the students' guide}

In the flipped classroom, the students who have a definite learning object can learn English with a high autonomy. The teachers should be a good guide for their students. Such as, guiding students to collect learning materials, and use different learning resources, especially those English teaching resources with native speakers. ${ }^{[7]}$ The role of teacher has gradually become the guide or helper of students' learning from the main speaker in the traditional classroom, and it is important for teachers to carefully find and screen the English materials in a large number of resources which are appropriate and beneficial to students' English learning.

\section{B. The Role of An Organizer of the Learning Tasks}

English teachers are required to collect, analyze and organize daily oral practice, listening, reading, writing, dialogues for communication etc. For different student, the teachers should educate students in accordance with their aptitude and make the formulation of the plan for students in various stages to complete the task. In the classroom, teachers are the organizers for the arrangement of classroom activities. In the circumstance, teachers can create a personalized learning environment for students.

\section{The Role of Students' Partner in the Learning Process}

Teachers become the students' partner in the learning process. And teachers are required to walk down the platform to communicate with students in the process, so that 
they are able to establish a relationship with the students like friends. At the beginning, most of the students are alert to the teachers and even have some fear when communicate with teachers. But, when the students have learned of their respect and support from the teachers, they will open the mind and enquire the teachers with the true expression of ideas and the confusion in their learning process. ${ }^{[8]}$ When communicating with students, teachers should carefully observe the characteristics of each student, understand their strengths and weaknesses, and arrange the targeted guidance, try to explore each student's potential ability. In addition, teachers should encourage students to use English during their talk, which can cultivate their ability of English listening and speaking.

\section{The Role of Assessment on Learning Effects}

Teachers are required to provide guidance in the class and online, which can help students to correct their mistakes, and in the process of correction, they can strengthen the memory and understanding of new knowledge through the various tests provided by the teacher. Those tests are the assessment for the students' learning. If the students are through the assessment, they can continue to acquire knowledge in next step; if they fail to pass the exam, they are required to watch the video again, and they can ask for help from the teacher. Thus, this role of a teacher is quite important. It is of great importance in the evaluation and summary of the learning process, because it is not only to evaluate before the following learning, but also to remove the obstacles for the following learning.

Therefore, compared with the traditional mode of teaching, the flipped classroom has great advantages in College English teaching. After the flipped classroom, teachers can not only assess the state of knowledge absorption and understanding, help students to eliminate confusion on the new knowledge, but also pay attention to students' oral ability and help students improve their ability to speak in English. In the implementation of the initial stage, many students can not adapt to the new teaching mode, and do not know how to learn. Even it appears the conflicting emotion when the learning effect is not ideal. So when encountering this kind of situation, teachers should make timely guidance and encourage students, helping them adapt to the situation. In the course of flipped classroom, it is easy for teachers encountering many doubts, and the teachers have to take a great risk. On the one hand, teachers have to face their own challenges that the flipped classroom is a new mode of teaching, which is lack of the research and practice in this field in China, especially in English teaching. On the other hand, it is difficult for teachers to learn from the theoretical guidance and practical experience. Thus, teachers should rely on their own ability to explore. In addition, in the teaching mode of flipped classroom, the process of learning knowledge is required to move to the time after the class, which is conducive to teach the students and help them adjust the learning progress according to their individual abilities.

\section{CONCLUSION}

In summary, the flipped classroom is a new and interesting lively teaching mode in the class, which is conducive to build a harmonious relationship between teachers and students. The application of the teaching mode of the flipped classroom in the English teaching of minority preparatory education will greatly enhance the efficiency and quality of English teaching, improve students' learning interest and enthusiasm, and avoid the teaching problem on various English learning levels of students, which opens up a new way of teaching reform. The application of the flipped class is conducive to enhance students' autonomous learning ability, build a harmonious relationship between teachers and students, and create a good learning atmosphere. With the constantly deepened reform of English teaching, the teaching mode of the flipped classroom will get more extensive attention and development.

\section{REFERENCES}

[1] Kathleen F. Upside Down and Inside Out: Flip Your Classroom to Improve Student Learning $[\mathrm{J}]$. Learning and Leading with Technology, 2012(6).

[2] Wang Haijie, Zhang Li. The Application of Flipped Classroom in English Teaching[J]. Teaching and Management, 2014 (7).

[3] Pang. Weiguo. On Students' Autonomous Learning[J]. Journal of East China Normal University (SOCIAL SCIENCE EDITION), 2001 (2).

[4] Wu Zefeng. Harmonious Relationship Between Teachers and Students Promotes English Teaching[J]. Journal of Shanxi University of Finance and Economics, 2012 (2).

[5] Wen Tianmin. Exploration and Practice on Individualized Education [J]. Research on Curriculum Education, 2013 (26).

[6] Zhang Jinlei, Wang Ying, Zhang Baohui. Research on the Teaching Mode of the Flipped Classroom[J]. Remote Education, 2012 (4).

[7] Shang Fang. The Evaluation of Vocational College English Teaching Mode of Flipped Class[J]. College Education, 2014 (11).

[8] Zhao Xinglong. The Design of Flipped Class Teaching Mode and the Process of Internalization of Knowledge in the Classroom[J]. Research on Modern Remote Education, 2014 (2). 